\title{
Evaluation of the diet supplementation strategy on the flesh quality and fatty acid profiles in common carp (Cyprinus carpio L)
}

\author{
Dejana Trbovicl, Vesna Djordjevic ${ }^{*}$, Aurelija Spiric ${ }^{l}$, Radivoj Petronijevic ${ }^{1}$, Vlado Teodorovic², \\ Nenad Parunovic ${ }^{1}$, Zoran Markovic ${ }^{3}$
}

A b s tra c t: The objective of this study was to evaluate the influence of three supplementary diets on the nutritional quality of marketable common carp. Supplementary diets (Carp1-maize, Carp2-extruded and Carp3-pelleted feed) exhibited significantly different ( $p \leq 0.05)$ influences on the protein, lipids, moisture and ash content in market-sized carp. The most abundant saturated FA (SFA) was palmitic acid (C16:0), the most predominant monounsaturated FA (MUFA) was oleic acid (C18:1n-9), and the most abundant polyunsaturated FA (PUFA) was linoleic acid (C18:2n-6). The highest content of SFAs was established in Carp1 $(24.57 \%$ and 1888.72 $\mathrm{mg} / 100 \mathrm{~g}$ wet fillet). MUFAs were presented in the highest quantities $(61.77 \%$, i.e. $4854.91 \mathrm{mg} / 100 \mathrm{~g}$ wet fillet) in Carp1, and PUFA accounted the highest quantities $(33.48 \%$, i.e. $1763.01 \mathrm{mg} / 100 \mathrm{~g}$ wet fillet) in Carp3. The most nutritionally beneficial $n-6 / n-3 \mathrm{ratio}$ was obtained in Carp2 (5.83). The results obtained in this study indicate that introducing supplementary diets containing extruded or pelleted feed instead of maize improved carp nutritional quality. PCA (principal component analysis) and LDA (linear discriminant analysis) of the FAs demonstrated that carp could be reliably classified based on their supplementary feed.

Key words: common carp, supplementary diets, proximate composition, fatty acid profiles.

\section{Introduction}

The lipid content and fatty acid (FA) composition differ greatly within fish species depending on various conditions, including the type and availability of food and/or feed, the state of the ecosystem inhabited by the fish, the environmental conditions, season, and age (Kaçar et al., 2016; Ljubojevic et al., 2013a; Ivanovic et al., 2015). However, fish feed is the most responsible of these factors for the FA profile of fish, and evidence suggests that under similar farming conditions fish feed rich in $n-3$ FAs decreases the n6/n-3 PUFA ratio in the fish tissue (Tesic et al., 2014). The FA composition of farmed fish differs from the FA composition of fish from open waters (Ljubojevic et al., 2013b). The growing demand for food in densely populated or less developed countries is partially satisfied through aquaculture with cyprinid fish species (Jeney \& Jian, 2009). The farming of cyprinid fish species is more developed in Asia and in central and eastern European countries (Váradi et al., 2012). The dominant form of cyprinid production is the semi-intensive farming of common carp (Cyprinus carpio L.) where the diet of the fish is based primarily on a combination of natural food and supplementary feed (cereals, such as wheat, maize and barley) (Mráz et al., 2012). To improve the production and nutritional value of the carp over the last decade, cereals have been replaced by pelleted and extruded feed (Tkaczewska et al., 2014). Research into carp aquaculture became more focused on the evaluation of the supplemental feed type that is essential for increasing carp production (Ciric et al., 2015) and on nutritional quality of the fish under the influence of different food/feed type (Böhm et al., 2014).

Although carp production is widespread in the world, data on the nutritional quality of marketable carp are limited in the literature. In Serbia, carp is also the most cultivated fish species, and is considered as a valuable fishery product and a traditional dish. Therefore, the aim of this study was: (a) to evaluate the influence of three supplementary diets (maize, extruded and pelleted feed) on the proximate composition and FA profile of marketable common carp collected

${ }^{1}$ Institute of Meat Hygiene and Technology, Kacanskog 13, 11000 Belgrade, Republic of Serbia;

2University of Belgrade, Faculty of Veterinary Medicine, Bulevar Oslobodjenja 18, 11080 Belgrade, Republic of Serbia;

${ }^{3}$ University of Belgrade, Faculty of Agriculture, Nemanjina 6, 11080 Belgrade - Zemun, Republic of Serbia.

${ }^{*}$ Corresponding author: Vesna Djordjevic, vesnazdjordjevic@gmail.com 
from three commercial fish farms using semi-intensive farming conditions, and (b) based on the obtained data to derive conclusions about the nutritional quality of the carp offered to commercial market.

\section{Materials and methods}

According to the opinion of the Ethics Commission of the Institute of meat hygiene and technology (Opinion No. 3294) all experimental procedures conducted in this study have been performed in accordance with the national Animal Welfare Act (2009).

\section{Samples}

For the study, two and a half years old market-sized carp $(n=8)$ were obtained in October 2015 from three commercial carp farms from batches of fish harvested for the market. The fish farms were

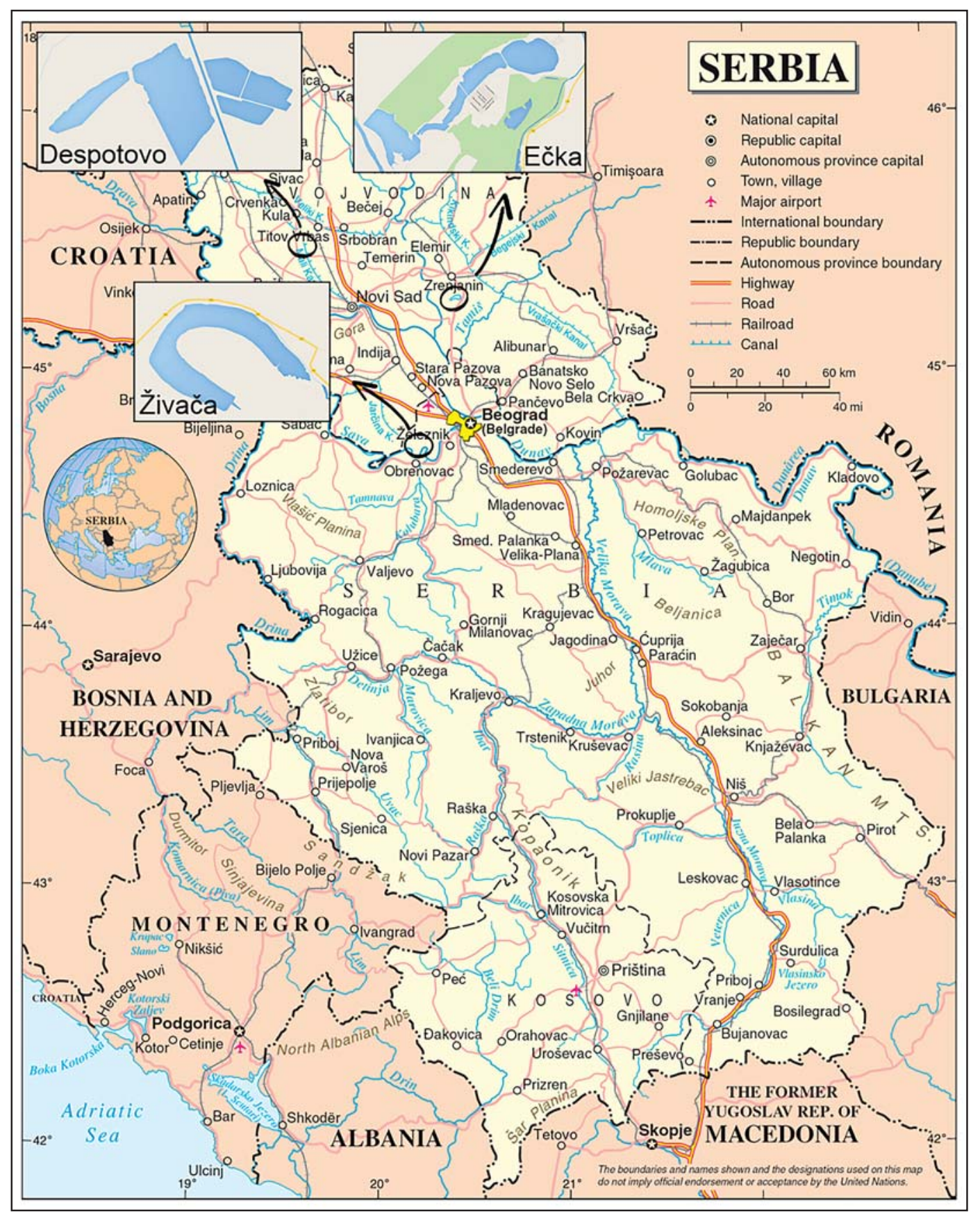

Figure. 1 The geographical positions (GPS data) of the fish farms. (Zivaca: Carp supplementary fed maize) latitude 44.73, longitude 20.18; Ecka: (Carp supplementary fed extruded feed) latitude 45.24, longitude 20.36; Despotovo: (Carp supplementary fed pelleted feed) latitude 45.45, longitude 19.54) 
located in Vojvodina, the lowland part of Serbia (Fig. 1), and all of them practiced semi-intensive aquaculture.

From April until they were harvested for the market, in October 2015, the carp were fed commercial diets supplemented with maize (Carp1), extruded feed (Carp2), which consisted of $61 \%$ maize, $30 \%$ soybean meal, $3 \%$ fish meal, $3 \%$ yeast, $0.8 \%$ chalk, $0.2 \%$ lysine, $1 \%$ vitamin premix and $1 \%$ other ingredients, and pelleted feed (Carp3), which consisted of $28 \%$ soybeans, $5 \%$ fish meal, $6 \%$ yeast, $22 \%$ wheat, $30 \%$ maize, $6.4 \%$ soybean meal, $0.8 \%$ chalk, $0.20 \%$ lysine, $1 \%$ vitamin premix, $0.8 \%$ monocalcium phosphate and $0.1 \%$ salt. The mean body weights of the live fish at harvest were $1,834 \pm 443 \mathrm{~g}$ for Carp 1 fed maize, $1,984 \pm 322 \mathrm{~g}$ for Carp2 fed extruded feed, and $2,235 \pm 423 \mathrm{~g}$ for Carp3 fed pelleted feed. The proximate and FA composition of the supplementary diets are shown in Table 1.

After the fish were caught, the percussive stunning method has been carried out (EFSA, 2009), and afterwards the slaughtered fish were transported to the laboratory in coolers with ice. After removal of the skin, heads, tails, fins, and intestines, the fish were deep-frozen and maintained at $-25^{\circ} \mathrm{C}$ until analysis, but no longer than two weeks. Before the analysis, the frozen fish were allowed to equilibrate at room temperature for an hour. The obtained fish fillets were individually disintegrated in a CombiMax 600 blender (Braun GmbH, Kronberg, Germany).

\section{Proximate composition}

The protein content $(\mathrm{N} \times 6.25)$ in the fish was determined using the Kjeldahl procedure on a Kjeltec Auto 1030 Analyser (Manual book, Tecator, Höganäs, Sweden). The moisture content was determined by drying the sample at $103 \pm 2^{\circ} \mathrm{C}$ to a constant mass based on the ISO 1442:1997 method. The total fat content was determined by extraction with petroleum ether in a Soxhlet apparatus, after the sample was hydrolysed with acid, based on the ISO 1443:1973 method. The ash content was determined gravimetrically through dry ashing in a muffle furnace at $550 \pm 25^{\circ} \mathrm{C}$ based on the ISO 936:1998 method.

Fish feed was analysed for its lipid (ISO 6492:1999), moisture (ISO 6496:1999), ash (ISO 5984:2002) and crude protein contents (Kjeldahl method using a conversion factor of 6.25 for the total nitrogen). The crude fibre content was determined using a standard method with intermediate filtration (ISO 6865:2000). The nitrogen-free extract (NFE) was calculated by adding the values obtained for moisture, crude protein, lipid, crude fibre and ash, and subtracting the sum from 100. All proximate composition analyses were performed in triplicate.

Table 1. Proximate and FA composition of the diets

\begin{tabular}{lrcc}
\hline Proximate composition (\%) & Maize & Extruded feed & Pelleted feed \\
\hline Crude protein & 8.58 & 24.96 & 22.22 \\
Lipids & 4.47 & 8.17 & 5.43 \\
Moisture & 11.64 & 9.66 & 8.27 \\
Ash & 1.10 & 6.81 & 6.61 \\
Crude fibre & 1.71 & 3.12 & 3.17 \\
Nitrogen-free extract (NFE) & 72.50 & 47.28 & 54.30 \\
\hline Fatty acids (\% of total FAs) & & & \\
\hline C18:2n-6 & 56.15 & 54.02 & 54.96 \\
C18:3n-3 & 0.98 & 1.62 & 3.74 \\
$\mathbf{\Sigma S F A}$ & 13.84 & 14.02 & 15.47 \\
$\mathbf{\Sigma M U F A}$ & 28.15 & 27.73 & 25.62 \\
$\mathbf{\Sigma}$ PUFA & 58.00 & 58.18 & 58.91 \\
n-6 & 57.03 & 54.69 & 55.13 \\
n-3 & 0.98 & 3.49 & 3.78 \\
n-6/n-3 & 58.19 & 15.67 & 14.59 \\
\hline
\end{tabular}

FA fatty acid, SFA saturated fatty acid, MUFA monounsaturated fatty acid, PUFA polyunsaturated fatty acid 


\section{Extraction of total lipids}

The total lipids used to determination the FA contents were extracted from fish fillets through accelerated solvent extraction (ASE), (ASE 200, Dionex, Sunnyvale, CA, USA). The operating conditions were the same as previously reported (Spiric et al., 2010). Briefly, after consecutively loading the Dionex extraction cell with diatomaceous earth and a homogenised fish fillet sample, the cells were extracted with a mixture of $n$-hexane and isopropanol $(60: 40, \mathrm{v} / \mathrm{v})$ at $100^{\circ} \mathrm{C}$ over two static cycles under nitrogen at $10.3 \mathrm{MPa}$. The solvent from the collected extracts was removed under a stream of nitrogen (Dionex Solvent evaporator 500) at $50^{\circ} \mathrm{C}$ until dry. The ASE method for extracting lipids from fish fillets has been previously validated and accredited.

\section{Fatty acids}

FAMEs were prepared by transesterifying the lipids extracted through ASE using 0.25 M TMSH based on the ISO 5509:2000 method. The FAMEs were analysed on a Shimadzu 2010 gas chromatograph (Kyoto, Japan) equipped with a split/splitless injector, a fused silica cyanopropyl HP-88 column (J\&W Scientific, Santa Clara, USA) (length $=100 \mathrm{~m}$, i.d. $=0.25 \mathrm{~mm}$, film thickness $=0.20 \mu \mathrm{m}$ ), a flame ionisation detector, and a workstation. The injector and detector temperatures were $250^{\circ} \mathrm{C}$ and $280^{\circ} \mathrm{C}$, respectively. To achieve complete separation of the tested compounds, a programmed column oven temperature, starting at $125^{\circ} \mathrm{C}$ and ending at $230^{\circ} \mathrm{C}$, was applied.

The chromatographic peaks in the samples were identified by comparing their relative retention times to the FAME retention times in the Supelco 37 Component FAME mix standard (Supelco, Bellefonte, USA). The relative quantities of FAs, which were expressed as the weight percentages of the total FAs, were converted to mg of FA per $100 \mathrm{~g}$ of wet fillet (wf) based on the method described by Exler et al. (1975).

\section{Statistical analysis}

The obtained data are reported as the mean values \pm the standard deviations. ANOVA and the Tukey-Kramer test were used to analyse the data at the level of significance of $0.05(p \leq 0.05)$. PCA and LDA were performed using JMP 10 software (SAS Institute Inc. NC, USA https://www.jmp.com).

\section{Results and discussion}

\section{Proximate composition}

The proximate compositions (protein, total lipids, moisture and ash) of the market-sized carp supplemented with different diets are presented in Table 2.

The data obtained show that different diets led to differences in the chemical composition of the fish, as reported by Shearer (1994). Significant differences $(p \leq 0.05)$ in protein content were observed between Carp1, which were fed supplementary maize (16.12\%), Carp2, which were fed supplementary extruded feed (17.26\%) and Carp3, which were fed supplementary pelleted feed (18.42\%). Cirkovic et al. (2011) reported similar results for proteins in carp farmed in polyculture in carp ponds in Serbia. Carp fed supplementary maize contained $8.59 \%$ lipids $(\mathrm{p} \leq 0.05)$, a higher content than in carp fed supplementary extruded feed $(4.72 \%)$ and in carp fed supplementary pelleted feed $(5.42 \%)$. However, from the data presented in Table 1, the NFE content, which is considered as a measure of soluble carbohydrates such as starch and sugar in the feed, accounted for $72.50 \%, 47.28 \%$ and $54.30 \%$ of the weight in maize, extruded and pelleted diets, respectively. Literature data (Henderson, 1996) demonstrates that fish diet rich in carbohydrates, such as maize, increased the synthesis of FAs and led to higher lipid content in the carp. Taking into consideration the geographical distribution of the fish farms, variation in amounts of natural and/or supplementary food/feed, environmental

Table 2. Proximate composition (\% wf) of market-sized carp (Cyprinus carpio L.) ( $\mathrm{n}=8)$

\begin{tabular}{lccc}
\hline Parameters & Carp1 & Carp2 & Carp3 \\
\hline Protein & $16.12 \pm 0.92^{\mathrm{a}}$ & $17.26 \pm 0.30^{\mathrm{b}}$ & $18.42 \pm 0.62^{\mathrm{c}}$ \\
Total lipids & $8.59 \pm 0.34^{\mathrm{a}}$ & $4.72 \pm 0.71^{\mathrm{b}}$ & $5.42 \pm 1.04^{\mathrm{b}}$ \\
Moisture & $73.01 \pm 2.63^{\mathrm{a}}$ & $75.72 \pm 0.93^{\mathrm{b}}$ & $73.41 \pm 1.55^{\mathrm{a}}$ \\
Ash & $0.96 \pm 0.04^{\mathrm{a}}$ & $1.12 \pm 0.06^{\mathrm{b}}$ & $1.33 \pm 0.10^{\mathrm{c}}$ \\
\hline
\end{tabular}

Legend: Values are means $\pm \mathrm{SD}$; ${ }^{a, b, c}$ Means with different letters within the same row are significantly different ( $\left.\mathrm{p} \leq 0.05\right)$; wf wet fillet; $\mathrm{n}$ number of samples; Carp1 supplementary fed maize; Carp2 supplementary fed extruded feed; Carp3 supplementary fed pelleted feed 
conditions, etc, it can be considered that the lipid contents obtained in this study are similar to other reported data for the farmed carp (Cirkovic et al., 2011; Trenovszki et al., 2011). Regarding fat content, according to literature data (Ackman, 1989), carp fed supplementary maize can be considered as a fatty fish $(>8 \%)$, while carp fed supplementary extruded and pelleted feed are considered as a medium fatty fish (4-8\%). Due to differences in the mineral content of the diets, the ash content among the studied carp differed significantly $(\mathrm{p} \leq 0.05)$, ranging from $0.96 \%$ to $1.33 \%$. However, other endogenous (genetic, like size, sex and life cycle stage) and exogenous (environment, like temperature, salinity, etc.) factors might also affect the proximate composition of the fish, including ash content (Shearer, 1994).

\section{Fatty acids expressed as relative percentage of total fatty acids}

The FA compositions of the carp supplemented with maize (Carp1), extruded (Carp2) and pelleted feed (Carp3), expressed as percentage of the total FAs and $\mathrm{mg} / 100 \mathrm{~g}$ wf are presented in table 3 .

The proportions of SFAs in the carps did not reflect their proportions in the diets. These results are similar to other reported data in carp supplied with supplementary feed diets (Mráz et al., 2012).

The MUFA contents were $61.77 \%$ in the carp supplemented with maize, $43.45 \%$ in the carp supplemented with extruded feed and $43.46 \%$ in the carp supplemented with pelleted feed, which reflect their contents in the applied supplementary diets. The content of MUFAs in the carp fed supplementary maize was significantly higher $(p \leq 0.05)$ than in the carp fed supplementary extruded or pelleted feed. No significant difference was observed in the MUFA contents in the carp supplemented with extruded and pelleted feed $(\mathrm{p} \geq 0.05)$. Among the individual MUFAs, oleic acid (C18:1n-9) was the most abundant FA in the carp, and it was significantly higher $(\mathrm{p} \leq 0.05)$ in carp fed supplementary maize $(50.43 \%)$ than in carp fed supplementary extruded $(34.11 \%)$ or pelleted $(37.83 \%)$ feed. Evidence in the literature (Farkas et al., 1978; Henderson, 1996) suggests that supplementary diets rich in carbohydrates (maize, wheat) lead to increased de novo synthesis of oleic acid in the carp, which led to around 1.5 times higher content of MUFAs in the carp fed supplementary maize compared to carp fed supplementary extruded or pelleted feed.

The total PUFA content was the highest in carp supplemented with pelleted feed $(33.48 \%)$, and was followed by carp supplemented with extruded feed (31.53\%). The lowest PUFA content was observed in the carp supplemented with maize (12.89\%). Differences in the PUFA contents between carps supplemented with extruded and pelleted feed were not statistically significant $(\mathrm{p} \geq 0.05)$, while carp supplemented with maize contained significantly lower amounts of PUFAs $(p \leq 0.05)$. However, the contents of PUFAs in the carp were not correlated with the quantities of PUFAs in the supplementary feeds $(58.00 \%, 58.18 \%$ and $58.91 \%$ in maize, extruded and pelleted feed, respectively). Linoleic acid (C18:2n-6) was the most abundant PUFA in carp, comprising $10.19 \%, 25.01 \%$ and $28.01 \%$ of total FAs in carp supplemented with maize, extruded and pelleted feed, respectively. The linoleic acid (C18:3n-3) contents in the carps fed supplementary extruded and pelleted feed were 2.45 and 3.75 fold higher than in the carp fed supplementary maize, even though the content of this FA in the diets was similar $(56.15 \%, 54.02 \%$ and $54.96 \%$ in the maize, extruded and pelleted feed, respectively). Literature data suggests that carp preferentially retain PUFAs from diets (Böhm et al., 2014). This indicates that other effects (e.g. different metabolic pathways, zooplankton levels in fishponds, etc.) apart from diets were involved (Henderson, 1996).

Carp supplemented with pelleted feed contained the highest proportion of $n-6$ PUFAs $(30.14 \%)$, followed by carp supplemented with extruded feed $(26.91 \%)$ and carp supplemented with maize $(11.89 \%)$. The differences in the $n-6$ PUFA contents were statistically significant $(\mathrm{p} \leq 0.05)$. The content of $n-3$ PUFAs was the highest in the carp supplemented with extruded feed (4.62\%), followed by the carp supplemented with pelleted feed $(3.33 \%)$, and the lowest was in the carp supplemented with maize $(1.00 \%)$. The differences were statistically significant $(\mathrm{p} \leq 0.05)$. The proportion of linolenic acid, which was the most abundant n-3 PUFA in the carp, was the highest in the carp supplemented with pelleted feed $(2.53 \%)$, followed by the carp supplemented with the extruded feed $(2.26 \%)$, and the lowest was in the carp fed supplementary maize $(0.63 \%)$, which is a consequence of the linolenic acid content in the carp feed (Buchtová et al., 2007). The EPA (C20:5n-3) and DHA (C22:6n-3) contents were lower in the carp supplemented with maize $(0.11 \%$ and $0.13 \%$, respectively) and higher in the carp supplemented with extruded $(0.58 \%$ and $1.01 \%$, respectively) and pelleted $(0.24 \%$ for both FAs) feed. The reason for higher quantities of EPA and DHA in the carp supplemented with extruded and pelleted feeds might be higher quantities of linolenic acid in the diets and the increased digestibility of these diets, which affected their utilisation by the fish (Takeuchi, 1996). Some literature data (Böhm et al., 2014) indicate that different diets led to significant variations in the MUFA, $n-6$ and $n-3$ PUFA 
Table 3. FA composition of carp (Cyprinus carpio L.) ( $\mathrm{n}=8)$ supplementary fed different diets (\% of total FAs and $\mathrm{mg} / 100 \mathrm{~g}$ wf)

\begin{tabular}{|c|c|c|c|c|c|c|}
\hline \multirow{2}{*}{ Fatty acids } & \multicolumn{2}{|c|}{ Carp1 } & \multicolumn{2}{|c|}{ Carp2 } & \multicolumn{2}{|c|}{ Carp3 } \\
\hline & (\% of total FA) & (mg/100 g wf) & (\% of total FA) & (mg/100 g wf) & ( $\%$ of total FA) & $(\mathrm{mg} / 100 \mathrm{~g} \mathrm{wf})$ \\
\hline C14:0 & $0.71 \pm 0.07^{\mathrm{b}}$ & $58.30^{x}$ & $0.84 \pm 0.07^{\mathrm{a}}$ & $38.09^{y}$ & $0.46 \pm 0.06^{c}$ & $25.55^{y}$ \\
\hline C15:0 & $0.09 \pm 0.02^{b}$ & $7.20^{\mathrm{x}}$ & $0.19 \pm 0.04^{\mathrm{a}}$ & $8.17^{\mathrm{x}}$ & $0.13 \pm 0.06^{\mathrm{b}}$ & $7.26^{x}$ \\
\hline C16:0 & $18.73 \pm 1.27^{\mathrm{a}}$ & $1423.42^{x}$ & $17.81 \pm 0.76^{\mathrm{ab}}$ & $806.54^{y}$ & $16.76 \pm 0.70^{\mathrm{b}}$ & $886.76^{\mathrm{y}}$ \\
\hline C16:1 & $6.95 \pm 0.76^{\mathrm{a}}$ & $541.68^{x}$ & $5.01 \pm 0.83^{b}$ & $229.68^{\mathrm{y}}$ & $3.47 \pm 0.96^{c}$ & $189.85^{\mathrm{y}}$ \\
\hline C17:0 & $0.12 \pm 0.03^{b}$ & $10.37^{x}$ & $0.34 \pm 0.08^{\mathrm{a}}$ & $14.99^{\mathrm{x}}$ & $0.18 \pm 0.09^{b}$ & $9.85^{\mathrm{x}}$ \\
\hline C18:0 & $5.16 \pm 0.66^{\mathrm{a}}$ & $390.99^{x}$ & $4.49 \pm 0.28^{\mathrm{ab}}$ & $203.02^{\mathrm{y}}$ & $4.38 \pm 0.50^{\mathrm{b}}$ & $228.09^{\mathrm{y}}$ \\
\hline C18:1n-9 & $50.43 \pm 3.46^{\mathrm{a}}$ & $3968.34^{\mathrm{x}}$ & $34.11 \pm 2.37^{\mathrm{c}}$ & $1560.15^{y}$ & $37.83 \pm 2.89^{\mathrm{b}}$ & $2019.36^{y}$ \\
\hline C18:1n-7 & $2.67 \pm 0.20^{\mathrm{a}}$ & $211.93^{x}$ & $2.57 \pm 0.18^{\mathrm{a}}$ & $115.37^{\mathrm{y}}$ & ND & ND \\
\hline C18:2n-6 & $10.19 \pm 2.18^{c}$ & $737.25^{z}$ & $25.01 \pm 1.73^{b}$ & $1125.34^{y}$ & $28.01 \pm 1.56^{\mathrm{a}}$ & $1476.88^{x}$ \\
\hline C18:3n-6 & $0.24 \pm 0.05^{\mathrm{a}}$ & $19.07^{x}$ & $0.34 \pm 0.05^{\mathrm{a}}$ & $15.64^{x}$ & $0.33 \pm 0.16^{\mathrm{a}}$ & $15.88^{x}$ \\
\hline C18:3n-3 & $0.63 \pm 0.23^{b}$ & $54.62^{z}$ & $2.26 \pm 0.23^{\mathrm{a}}$ & $101.30^{y}$ & $2.53 \pm 0.24^{\mathrm{a}}$ & $133.42^{\mathrm{x}}$ \\
\hline C20:1n-9 & $1.76 \pm 0.26^{b}$ & $132.95^{x}$ & $1.76 \pm 0.24^{b}$ & $80.27^{y}$ & $2.16 \pm 0.17^{\mathrm{a}}$ & $114.32^{x . y}$ \\
\hline$C 20: 2 n-6$ & $0.31 \pm 0.06^{\mathrm{c}}$ & $23.76^{y}$ & $0.68 \pm 0.09^{b}$ & $30.35^{y}$ & $0.98 \pm 0.20^{\mathrm{a}}$ & $52.76^{x}$ \\
\hline$C 20: 3 n-6$ & $1.09 \pm 0.17^{\mathrm{a}}$ & $82.78^{x}$ & $0.88 \pm 0.10^{\mathrm{b}}$ & $39.61^{y}$ & $0.83 \pm 0.09^{b}$ & $43.33^{y}$ \\
\hline$C 20: 3 n-3$ & $0.04 \pm 0.08^{b}$ & $2.82^{y}$ & $0.48 \pm 0.11^{\mathrm{a}}$ & $21.03^{x}$ & $0.07 \pm 0.06^{\mathrm{b}}$ & $6.36^{y}$ \\
\hline $\begin{array}{l}C 22: 1 n- \\
9+20: 4 n-6\end{array}$ & $0.55 \pm 0.12^{b}$ & $45.35^{x}$ & $1.35 \pm 0.28^{\mathrm{a}}$ & $59.34^{x}$ & $1.14 \pm 0.51^{\mathrm{a}}$ & $59.17^{x}$ \\
\hline$C 20: 5 n-3$ & $0.11 \pm 0.08^{\mathrm{b}}$ & $8.62^{\mathrm{y}}$ & $0.58 \pm 0.14^{\mathrm{a}}$ & $25.66^{x}$ & $0.24 \pm 0.17^{\mathrm{b}}$ & $12.09^{y}$ \\
\hline $\mathrm{C} 22: 5 \mathrm{n}-3$ & $0.01 \pm 0.02^{\mathrm{b}}$ & $3.17^{\mathrm{y}}$ & $0.28 \pm 0.08^{\mathrm{a}}$ & $12.47^{x}$ & $0.19 \pm 0.12^{\mathrm{a}}$ & $9.50^{\mathrm{x}}$ \\
\hline $\mathrm{C} 22: 6 \mathrm{n}-3$ & $0.13 \pm 0.05^{b}$ & $11.04^{y}$ & $1.01 \pm 0.27^{\mathrm{a}}$ & $45.25^{\mathrm{x}}$ & $0.24 \pm 0.26^{\mathrm{b}}$ & $12.79^{y}$ \\
\hline ¿SFA & $24.57 \pm 1.29^{\mathrm{a}}$ & $1888.72^{x}$ & $23.66 \pm 0.80^{\mathrm{a}}$ & $1070.82^{y}$ & $21.91 \pm 0.98^{b}$ & $1157.55^{y}$ \\
\hline IMUFA & $61.77 \pm 3.99^{\mathrm{a}}$ & $4854.91^{x}$ & $43.45 \pm 2.78^{\mathrm{b}}$ & $1985.41^{\mathrm{y}}$ & $43.46 \pm 3.04^{b}$ & $2323.52^{y}$ \\
\hline ¿PUFA & $12.89 \pm 2.46^{b}$ & $944.94^{y}$ & $31.53 \pm 2.41^{\mathrm{a}}$ & $1416.65^{x}$ & $33.48 \pm 1.96^{\mathrm{a}}$ & $1763.01^{x}$ \\
\hline$n-6$ & $11.89 \pm 2.29^{c}$ & $862.87^{z}$ & $26.91 \pm 1.86^{\mathrm{b}}$ & $1210.95^{\mathrm{y}}$ & $30.14 \pm 1.62^{\mathrm{a}}$ & $1588.95^{x}$ \\
\hline$n-3$ & $1.00 \pm 0.27^{\mathrm{c}}$ & $72.57^{y}$ & $4.62 \pm 0.64^{\mathrm{a}}$ & $207.71^{x}$ & $3.33 \pm 0.43^{\mathrm{b}}$ & $175.57^{x}$ \\
\hline$n-6 / n-3 *$ & \multicolumn{2}{|c|}{$11.89 \pm 2.53^{\mathrm{a}}$} & \multicolumn{2}{|c|}{$5.83 \pm 0.56^{\mathrm{c}}$} & \multicolumn{2}{|c|}{$9.05 \pm 0.81^{\mathrm{b}}$} \\
\hline
\end{tabular}

Legend: Values are means $\pm \mathrm{SD}$; a,b,c; Means (\% of total FA) with different letters within the same row are significantly different $(\mathrm{p} \leq 0.05) ;{ }^{x, y, z}$ Means $(\mathrm{mg} / 100 \mathrm{~g})$ with different letters within the same row are significantly different ( $\left.\mathrm{p} \leq 0.05\right)$; wf wet fillet; $\mathrm{n}$ number of samples; Carp1 supplementary fed maize; Carp2 supplementary fed extruded feed; Carp3 supplementary fed pelleted feed; ND not detected; FA fatty acid; SFA saturated fatty acid; MUFA monounsaturated fatty acid; PUFA polyunsaturated fatty acid; * $\mathrm{n}-6 / \mathrm{n}-3$ ratio

contents in the carp, as well as in our study. The lowest $\mathrm{n}-6 / \mathrm{n}-3$ ratio was established in the carp fed extruded feed (5.83). Li et al. (2011) reported that low n3 PUFAs and high n6 PUFAs in the diets provided unfavourable $n-6 / n-3$ ratios in the fish.

Data we obtained in this study indicate that nutritional quality of common carp cultivated in commercial farms was, to a great extent, influenced by the composition of the applied supplementary diets. Aside from selective retention of the FAs from the applied diets in carp tissue, the state of the ecosystem, the availability of the natural food in the fish farms, the genetic differences between carp, water temperature (which is closely related to regional climate), pond management system, etc. probably had additional influences on the nutritional quality of the carp (Mráz et al., 2012; Tkaczewska et al., 2014). However, Trbovic et al. (2016) reported that the applied pelleted feed in a semi-intensive farming system of carp manifested dominant influence compared to natural food.

\section{Fatty acids expressed as fatty acid amounts} $(\mathrm{mg} / 100 \mathrm{~g} w f)$

When FAs in the fish are expressed as mg of FAs per $100 \mathrm{~g}$ of wf (Table 3), the obtained data are more important for consumers and demonstrate the nutritional value of the fish consumed per specific fish serving (Karakatsouli, 2012). 
The carp that were supplemented with maize cwontained significantly lower $(\mathrm{p} \leq 0.05)$ amounts of n-6 PUFAs than carp that were supplemented with extruded or pelleted feed. The amounts of $n-3$ PUFAs were the highest in the carp supplemented with extruded and pelleted feed $(p \leq 0.05)$. The quantities of EPA) and DHA were higher in the carp that were supplemented with the extruded feed than in the carp supplemented with the pelleted feed. Due to the benefits of n-3 PUFAs on human health and particularly the suppression of many diseases, the requirements for fish production and intake by humans is increasing worldwide $(F A O, 2014)$. However, clinical studies indicated that high amounts of n-6 PUFAs and high $n-6 / n-3$ ratios promote the pathogenesis of many diseases, and an optimal n- $6 / \mathrm{n}-3$ ratio, between $1: 1$ and $4: 1$, is more desirable for reducing the risk of disease (Simopoulos, 2002). The $\mathrm{n}-6 / \mathrm{n}-3$ ratio we obtained was more nutritionally beneficial in the carp that were supplemented with the extruded feed (5.83) and this ratio is closer to the ratio which was suggested by Simopoulos (2002) as optimal one.

\section{Statistical evaluation of data}

PCA performed on the FAs expressed as a percentage of the total FAs in the 24 carp samples provided better insight into the data structure. A biplot of the PCA score values for the first two principal

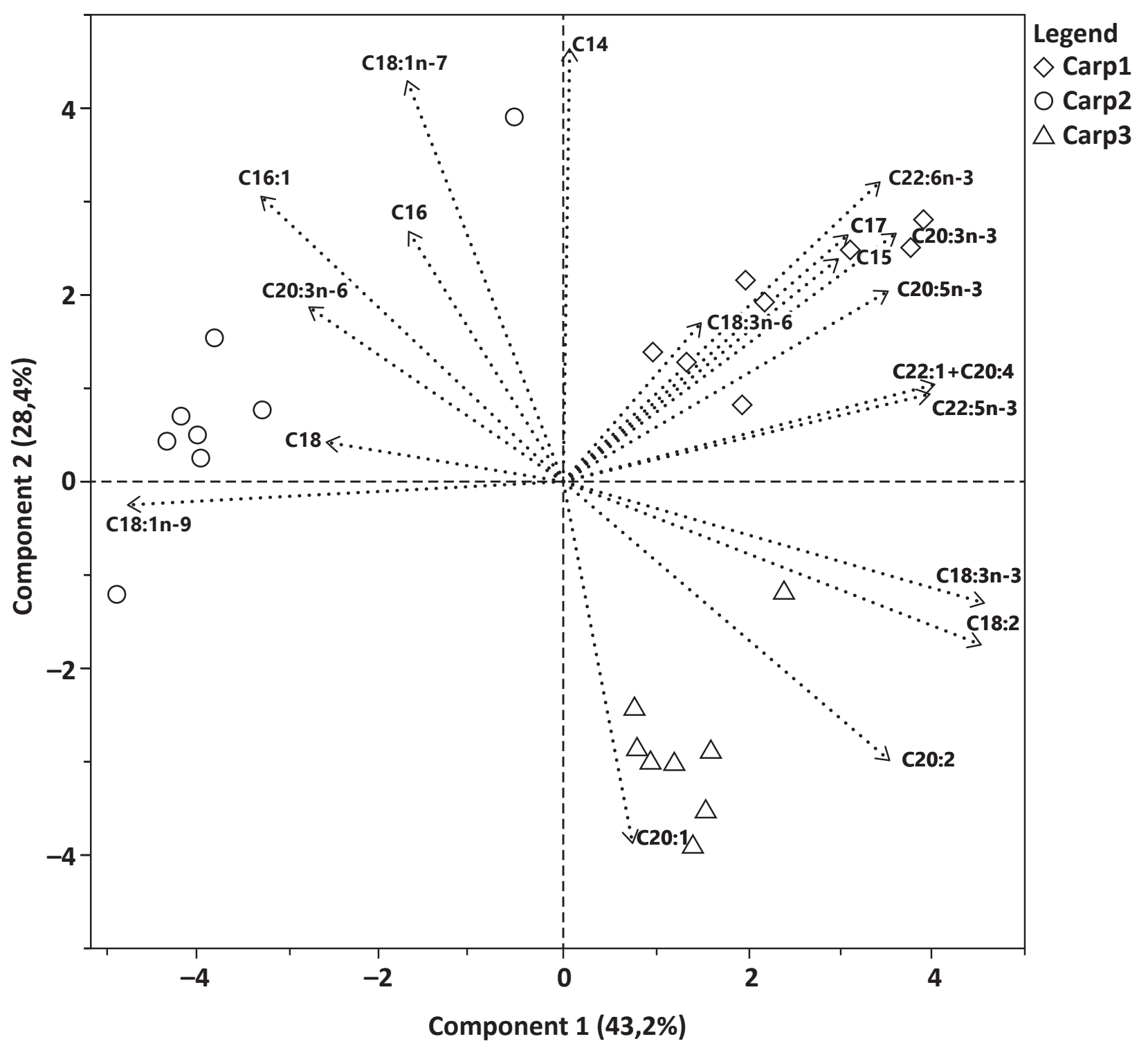

Figure 2. Biplot of PCA score values for the first two principal components of FAs expressed as percentage of the total FAs (Carp1 supplementary fed maize, Carp2 supplementary fed extruded feed,

Carp3 supplementary fed pelleted feed) 
components of FAs expressed as a percentage of the total FAs is shown in Figure 2.

The analysis resulted in a two-principal-component model that explained $71.6 \%$ of the total variance. The first principal component (PC1) accounted for $43.2 \%$, and the second (PC2) accounted for $28.4 \%$.

The score values for the first PC1 and PC2 of the FAs show that carp supplemented with maize (Carp1) were characterised by increased oleic, stearic (C18:0), dihomo- $\gamma$-linolenic (C20:3n-6) and palmitoleic (C16:1) FA contents. The carp supplemented with extruded feed (Carp2) were characterised by higher contents of the DHA, eicosatrienoic (C20:3n-3) FA, EPA and DPA (docosapentaenoic acid, C22:5n-3). Higher contents of eicosenoic
(C20:1) and eicosadienoic (C20:2) FAs were observed in the carp supplemented with the pelleted feed (Carp3). The PCA showed that the carp supplemented with the extruded or pelleted feed had greater linolenic, linoleic, and $\gamma$-linoleic (C18:3n-6) FA contents compared to the carp supplemented with maize.

Preliminary statistical evaluation showed that PCA was unsuitable to evaluate the FAs expressed as $\mathrm{mg} / 100 \mathrm{~g}$ wf. Instead, LDA was applied. The first and the second discriminant function (Canonicall and Canonical2) were used to obtain the scoring coefficients. Canonicall comprised $84.8 \%$, while Canonical2 comprised $15.2 \%$ of the data variance. The canonical correlation, which involved Canonical1 and Canonical2, totalled 0.997 and

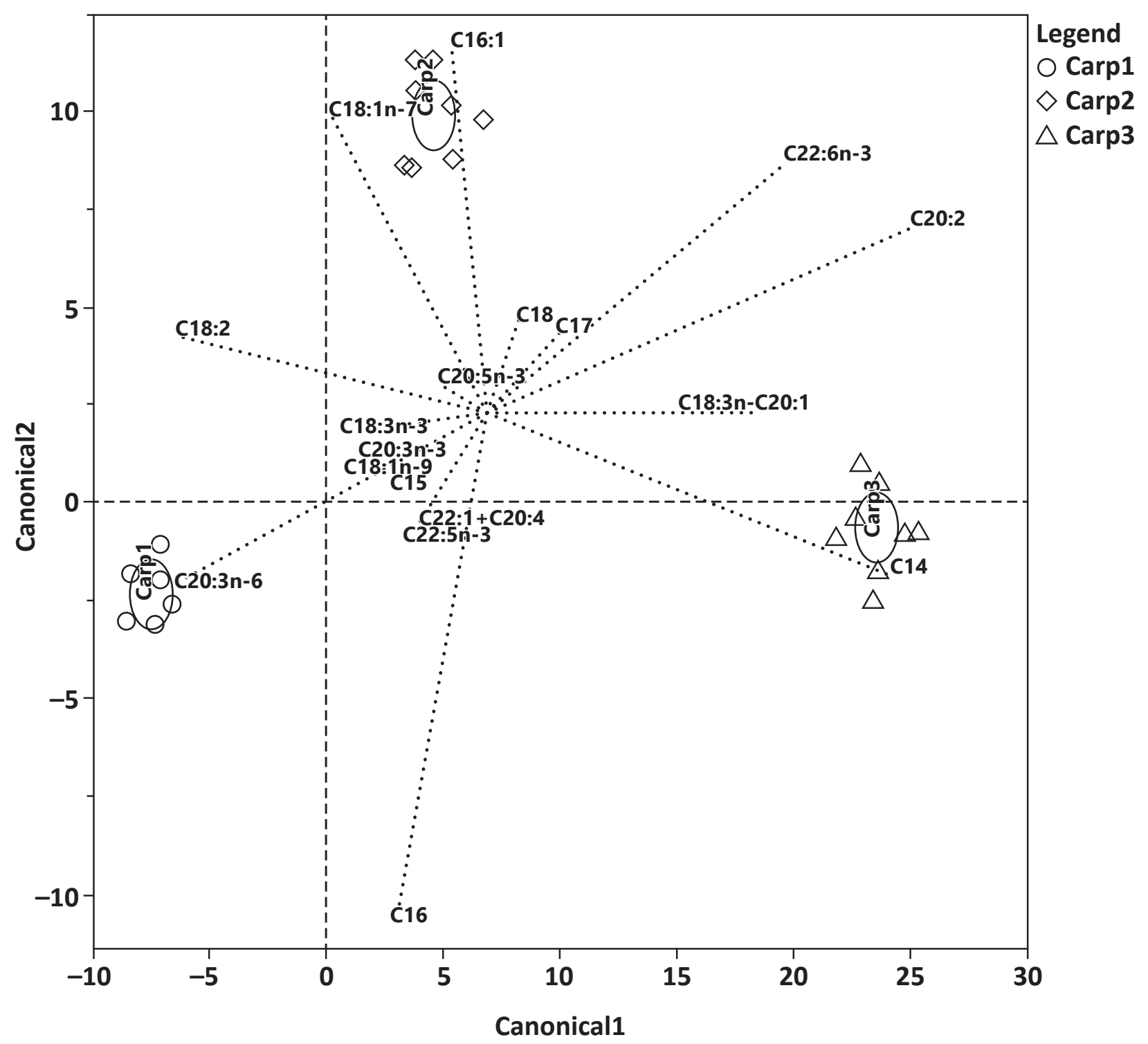

Figure 3. Canonical plot of the FAs expressed as FA amounts (mg/100 g wf) (Carp1 supplementary fed maize, Carp2 supplementary fed extruded feed, Carp3 supplementary fed pelleted feed 
0.985 , respectively. For discriminant analysis a total of 24 samples were used: eight samples from each group of fish. The number of misclassified samples was zero.

LDA of the FAs expressed as FA amounts $(\mathrm{mg} / 100 \mathrm{~g} \mathrm{wf})$ is presented in Figure 3.

All three groups of carps are clearly separated with no overlaps. Carp1 (supplemented with maize) are grouped in the lower left part of the figure, and have negative values for Canonicall and Canonical2. The Canonical1 and Canonical2 values for Carp2 (carp supplemented with pelleted feed) are positive, while Carp3 (carp supplemented with extruded feed) have positive values for Canonicall and negative values for Canonical2.

The differences in the FA contents among the groups strongly influenced the LDA grouping of the carp fed different diets. Carp1 differed from the other two groups (Carp2 and Carp3) based on dihomo- $\gamma$-linolenic FA contents. Carp2 differed from the other two groups based on palmitoleic FA content, and Carp3 differed from the other two groups based on the miristic FA content. The LDA of the FAs in the carp supplemented with different diets expressed as amounts of FAs (mg/100 g wf) shows that carp might be classified reliably based on the type of supplemental feed.

\section{Conclusions}

The results obtained in this study indicate that introducing supplementary diets containing extruded or pelleted feed instead of maize improved carp nutritional quality. The obtained $n-6 / n-3$ ratio is more nutritionally beneficial in the carp that were supplemented with the extruded feed, and this ratio is close to the optimal one. The PCA showed that the carp supplemented with the extruded or pelleted feed had greater linolenic, linoleic, and $\gamma$-linoleic FA contents compared to the carp supplemented with maize. The LDA of the FAs in the carp supplemented with different diets shows that carp might be classified reliably based on the type of supplemental feed. In general, great potential remains for improving feed quality and feeding strategy to achieve FA compositions of carp such that higher levels of n-3 PUFAs and more desirable n-6/n-3 ratios are obtained.

Acknowledgements: This research was supported by grants from the Ministry of Education and Science of the Republic of Serbia (Projects No. TR31075 and TR31011).

Disclosure Statement: No pontential conflict of interest was reported by the authors.

\section{References}

Ackman, R. G. (1989). Seafood lipids and fatty acids. Food Reviews International, 6, 617-646.

Böhm, M., Schultz, S., Koussoroplis, A-M. \& Kainz, M.J. (2014). Tissue-specific fatty acids response to different diets in common carp (Cyprinus carpio L.). PLoS ONE, 9, 1-8.

Buchtová, H, Svobodová, Z, Kř́zek, M, Vácha, F, Kocour, M \& Velísek, J. (2007). Fatty Acid Composition in Intramuscular Lipids of Experimental Scaly Crossbreds in 3-Year-Old Common Carp (Cyprinus carpio L.). Acta Veterinaria Brno, 76, 73-81.

Cahu, C., Salen, P. \& de Lorgeril, M. (2004). Farmed and wild fish in the prevention of cardiovasular diseases: Assessing possible differences in lipid nutritional values. Nutrition, Metabolism and Cardiovascular Diseases, 14, 34-41.

Ciric, M., Subakov-Simic, G., Dulic, Z., Bjelanovic, K., Cicovacki, S. \& Markovic, Z. (2015). Effect of supplemental feed type on water quality, plankton and benthos availability and carp (Cyprinus carpio L.) growth in semi-intensive monoculture ponds. Aquaculture Research, 46, 777-788.

Cirkovic, M., Trbovic, D., Ljubojevic, D. \& Djordjevic, V. (2011). Meat quality of fish farmed in polyculture in carp ponds in Republic of Serbia. Tehnologija mesa, 52, 106-121.
EFSA - European Food Safety Authority (2009). Scientific Opinion of the Panel on Animal Health and Welfare. Species-specific welfare aspects of the main systems of stunning and killing of farmed carp. EFSA Journal, 1013, 1-37.

Exler, J., Kinsella, J. E. \& Watt, B. K. (1975). Lipids and fatty acids of important finfish. New data for nutrient tables. Journal of the American Oil Chemists' Society, 52, 154-159.

FAO - Food and Drug Administration (2014). The State of World Fisheries and Aquaculture: Opportunities and challenges. Rome, ISBN 978-92-5-108275-1 (print).

Farkas, T., Csengeri, I., Majoros, F. \& Olah, J. (1978). Metabolism of fatty acids in fish. II. Biosynthesis of fatty acids in relation to diet of the carp, (Cyprinus carpio Linnaeus 1758). Aquaculture, 14, 57-65.

Ivanovic, J., Baltic, M. Z., Janjic, J., Markovic, R., Boskovic, M., Djordjevic, V., Dokmanovic, M., 2015. The scope and structure of the production and catch of the fish in Serbia in the period from 2006-2012. Veterinarski glasnik, 69 (1-2), 139-154.

Henderson, R. J. (1996). Fatty acid metabolism in freshwater fish with particular reference to polyunsaturated fatty acids. Archives of Animal Nutrition, 49, 5-22. 
Jeney, Z. \& Jian, Z. (2009). Use and exchange of aquatic resources relevant for food and aquaculture: common carp (Cyprinus carpio L.). Reviews in Aquaculture, 1, 163-173.

Kaçar, S., Başhan, M. \& Oymak, S. A. (2016). Effect of seasonal variation on lipid and fatty acid profile in muscle tissue of male and female Silurus triostegus. Journal of Food Science and Technology - Mysore, 53, 2913-2922.

Karakatsouli, N. (2012). An Overview of the Use of Fatty Acids in Fish Farming Research during the Last Decade, with Particular Emphasis on Fish Quality. Journal of the World Aquaculture Society, 43, 291-320.

Li, G., Sinclair, A.J. \& Li, D. (2011). Comparison of Lipid Content and Fatty Acid Composition in the Edible Meat of Wild and Cultured Freshwater and Marine Fish and Shrimps from China. Journal of Agricultural and Food Chemistry, 59, 1871-1881.

Ljubojevic, D., Cirkovic, M., Djordjevic, V., Puvaca, N., Trbovic, D., Vukadinov, J. \& Plavsa, N. (2013a). Fat quality of marketable fresh water fish species in the Republic of Serbia. Czech Journal of Food Science, 31, 445-450

Ljubojevic, D., Cirkovic, M., Djordjevic, V., Trbovic, D., Vranic, D., Novakov, N. \& Masic, Z. (2013b). Chemical composition, cholesterol content and fatty acid profiles of common carp (Cyprinus carpio) from free-catch, semi-intensive and cage system. Tehnologija Mesa, 54, 48-56.

Mráz, J., Máchová, J., Kozák, P. \& Pickova, J. (2012). Lipid content and composition in common carp - optimization of n-3 fatty acids in different pond production systems. Journal of Applied Ichthyology, 28, 238-244.

Shearer, K. D. (1994). Factors affecting the proximate composition of cultured fishes with emphasis on salmonids. $A q$ uaculture, 119, 63-88.

Simopoulos, A.P. (2002). The importance of the ratio of omega-6/omega-3 essential fatty acids. Biomedicine \& Pharmacotherapy, 56, 365-379.
Spiric, A., Trbovic, D., Vranic, D., Djinovic, J., Petronijevic, R. \& Matekalo-Sverak, V. (2010). Statistical evaluation of fatty acid profile and cholesterol content in fish (Common carp) lipids obtained by different sample preparation procedures. Analytica Chimica Acta, 672, 66-71.

Takeuchi, T. (1996). Essential fatty acid requirements in carp. Archiv für Tierernaehrung (Berlin) 49, 23-32.

Tesic, M., Baltic, M., Teodorovic, V., Nedic, D., Mirilovic, M., Markovic, R. \& Aleksic-Agelidis, A. (2014). Effects of various meal compositions on production results, economic performance and fish meat quality. Acta Veterinaria Beograd, 64, 338-348.

Tkaczewska, J., Migdal, W. \& Kulawik, P. (2014). The quality of carp (Cyprinus carpio L.) cultured in various Polish regions. Journal of the Science of Food and Agriculture, 94, 3061-3067.

Trbovic, D., Zivic, I., Stankovic, M., Zivic, M., Dulic, Z., Petronijevic, R. \& Markovic, Z. (2017). Dependence of the common carp (Cyprinus carpio L.) fatty acid profile on diet composition in a semi-intensive farming system: tissue and time variability. Aquaculture Research, 48, 3121-3133.

Trenovszki, M.M., Lebovics, V. K., Müller, T., Szabo, T., Hegyi, Á., Urbányi, B., Horváth, L. \& Lugasi, A. (2011). Survey of fatty acid profile and lipid peroxidation characteristics in common carp (Cyprinus carpio L.) meat taken from five Hungarian fish farms. Acta Alimentaria, 40, $153-164$

Váradi, L., Lane, A., Harache, Y., Gyalog, G., Békefi, E. \& Lengyel, P. (2012). Regional Review on Status and Trends in Aquaculture Development in Europe - 2010. In: FAO Fisheries and Aquaculture Circular. 1061/1, Rome, FAO 2010, pp 257. 